Archives of Agriculture and Environmental Science

\title{
Contamination, enrichment and translocation of heavy metals in certain leafy vegetables grown in composite effluent irrigated soil
}

\author{
Vinod Kumar $^{1^{*}}$ (D) , R.K. Chauhan ${ }^{2}$, Sachin Srivastava ${ }^{3}$, Jogendra Singh ${ }^{1}$ and Pankaj Kumar ${ }^{1}$ \\ ${ }^{1}$ Agro-ecology and Pollution Research Laboratory, Department of Zoology and Environmental Science, Gurukula Kangri University, \\ Haridwar-249404 (Uttarakhand), INDIA \\ ${ }^{2}$ Department of Chemistry, Indira Gandhi National College, Ladwa, Kurukshetra-136132 (Haryana), INDIA \\ ${ }^{3}$ Department of Forestry, Roorkee Institute of Technology-249404 (Uttarakhand), INDIA \\ *Corresponding author's E-mail: drvksorwal@gkv.ac.in
}

\section{ARTICLE HISTORY}

Received: 01 July 2018

Revised received: 20 August 2018

Accepted: 25 August 2018

\section{Keywords}

Accumulation

Composite effluent

Heavy metals

Hindon River

Translocation

Vegetables crops

\begin{abstract}
The present investigation was carried out to determine the contamination, enrichment and translocation of heavy metals in vegetables viz., spinach (Spinacia oleracea L.), fenugreek (Trigonella foenum-graecum L.) and coriander (Coriandrum sativum L.) grown in the composite effluent (mixture of industrial and domestic wastewater) irrigated soil. The composite effluent of Hindon River was significantly $(P<0.05 / P<0.01)$ loaded with different physical (TDS, EC), chemical ( $\left.\mathrm{pH}, \mathrm{BOD}_{5}, \mathrm{COD}, \mathrm{Cl}^{-}, \mathrm{TKN}, \mathrm{PO}_{4}{ }^{3-}, \mathrm{SO}_{4}{ }^{2-}, \mathrm{Na}^{+}, \mathrm{K}^{+}, \mathrm{Ca}^{2+}, \mathrm{Mg}^{2+}\right)$, heavy metals $(\mathrm{Cd}, \mathrm{Cr}, \mathrm{Cu}$, $\mathrm{Fe}, \mathrm{Mn}, \mathrm{Pb}, \mathrm{Zn}$ ) and microbial (total bacteria, total fungi, total coliform and yeast) parameters in comparison to the ground water. The composite effluent irrigation significantly $(P \leq 0.05)$ altered the soil characteristics like $\mathrm{EC}, \mathrm{pH}, \mathrm{PO}_{4}{ }^{3-}, \mathrm{K}^{+}, \mathrm{Cd}, \mathrm{Cr}, \mathrm{Cu}, \mathrm{Fe}, \mathrm{Mn}$ and $\mathrm{Pb}$ in the soil used for the cultivation of S. oleracea, $T$. foenum-graecum and $C$. sativum. The composite effluent irrigation significantly increased the contents of $\mathrm{Cd}, \mathrm{Cr}, \mathrm{Cu}, \mathrm{Fe}, \mathrm{Mn}, \mathrm{Pb}$ and $\mathrm{Zn}$ in the S. oleracea, T. foenum-graecum and $\mathrm{C}$. sativum. The enrichment factor of $\mathrm{Cd}, \mathrm{Cr}, \mathrm{Cu}, \mathrm{Fe}, \mathrm{Mn}, \mathrm{Pb}$ and $\mathrm{Zn}$ in vegetables was recorded to be plant part specific after irrigation with composite effluent. The enrichment factor of $\mathrm{Cd}, \mathrm{Cr}, \mathrm{Cu}, \mathrm{Fe}, \mathrm{Mn}, \mathrm{Pb}$ and $\mathrm{Zn}$ were recorded in the order of $\mathrm{Cd}>\mathrm{Zn}>\mathrm{Pb}>$ $\mathrm{Fe}>\mathrm{Cr}>\mathrm{Mn}>\mathrm{Cu}$ for $\mathrm{S}$. oleracea, $\mathrm{Cd}>\mathrm{Zn}>\mathrm{Fe}>\mathrm{Mn}>\mathrm{Pb}>\mathrm{Cr}>\mathrm{Cu}$ for $\mathrm{T}$. foenum-graecum and $\mathrm{Cd}>\mathrm{Zn}>\mathrm{Pb}>\mathrm{Fe}>\mathrm{Cu}>\mathrm{Mn}>\mathrm{Cr}$ for $\mathrm{C}$. sativum after irrigation with composite effluent. Therefore, disposal of sewage and industrial effluents in the Hindon River must be strictly prohibited to save the existence of the Hindon River and irrigation practices using composite effluent should also be banned to prevent the possible health hazards due to consumption of contaminated vegetables.
\end{abstract}

(C)2018 Agriculture and Environmental Science Academy

Citation of this article: Kumar, V., Srivastava, S., Chauhan, R.K., Singh, J. and Kumar, P. (2018). Contamination, enrichment and translocation of heavy metals in certain leafy vegetables grown in composite effluent irrigated soil. Archives of Agriculture and Environmental Science, 3(3): 252-260, https://dx.doi.org/10.26832/24566632.2018.030307

\section{INTRODUCTION}

The ever increasing human population, industrialization and urbanization severely deteriorated the quality of aquatic resources like pond, lakes, rivers and streams (Chopra et al., 2013; Kumar and Chopra, 2012a). The untreated or partially treated sewage and industrial effluents collectively is directly disposing in the aquatic environment (Kumar and Chopra, 2013, 2015; Pathak et al., 2011; Qadir et al., 2009). The domestic wastewater and industrial effluent contain an extensive range of chemicals, heavy metals and microbial pathogens. Pollution of the soil and water and agricultural crops with heavy metals is currently of great concern to human health (Arora et al., 2014; Chaturvedi et al., 2013; Kumar and Chopra, 2013). The enrichment of pollutants especially heavy metals in the water, soil and then in agricultural crops due to urbanization and industrialization is one of the major environmental problems globally (Chopra et al., 2013; Clemente et al., 2008). Heavy metals are 
considered one of the most widespread pollutant having toxic effects on plants and animals (Chopra et al., 2011; Kumar and Chopra, 2012b). These heavy metals come in to the environment from diverse industrial processes, domestic wastewater discharge and use of chemicals in agricultural practices (Sridhara et al., 2008; Al-Lahham et al., 2003). These metals enter in the living beings through food chain, accumulate, magnify and cause various health problems beyond a prescribed level (Kumar and Chopra, 2012a, b; Wang et al., 2007; Muchuweti et al., 2006; Sharma et al., 2006).

Globally, the fresh water resources are continuously shrinking due to over exploitation, pollution activities, uneven distribution of rain fall and frequent drought. On the other hand the use of aquatic resources as a medium for the disposal of the domestic and industrial wastewater is becoming increasingly common (FAO/WHO, 2011; Sharma et al., 2006; Yadav et al., 2002). In many developing countries, rivers are severely polluted due to the discharge of untreated or partially treated effluents (Javed et al., 2016; Kumar and Chopra, 2013; Chopra et al., 2013). The contaminated wastewater of these rivers is frequently used in the agricultural practices by the farmers due to the scarcity of irrigation water, high cost of chemical fertilizers and easy access and rich nutrients contents of wastewater. Therefore, use of contaminated wastewater in the cultivation of agricultural crops may enhance the contents of different heavy metals and microbial pathogens in the soil and then in the crop plants (Arora et al., 2014; Kumar and Chopra, 2012a, b).

Intake of contaminated vegetables with heavy metals and microorganisms may cause different health hazards (Muchuweti et al., 2006; Sharma et al., 2006). In the recent past various studies have been conducted on the characteristics of water flowing in different polluted rivers worldwide and their utilization in the cultivation of agricultural crops (Javed et al., 2016; Sharma et al., 2014; Lewis, 2007). Although, there are few scientific reports are available on the water quality of the Hindon River but comprehensive research should be required on the chemical, heavy metals and microbial load of water of the Hindon River, and their impact on the soil and cultivated agricultural crops in the vicinity of the Hindon River, India (Sharma et al., 2014; Lewis, 2007). Therefore, regular monitoring of the water quality of the rivers, its impact on soil and vegetable crops can prevent the possible health hazards due to the consumption of contaminated vegetables. Keeping in view the global river pollution and the importance of rivers in the developments, the present investigation was aimed to determine the contamination, enrichment and translocation of heavy metals in different leafy vegetables viz., spinach (Spinacia oleracea L.), fenugreek (Trigonella foenumgraecum L.) and coriander (Coriandrum sativum L.) grown in composite effluent irrigated soil in the vicinity of Hindon River, India.

\section{MATERIALS AND METHODS}

\section{Description of study area}

The present investigation was carried out in the vicinity of
Hindon River at Saharanpur (Uttar Pradesh), India (Figure 1). The Hindon River is originated form Shivalik Hills of Western Himalaya. The Hindon River is a tributary of the Yamuna River and flows (total catchment area $7083 \mathrm{Km}^{2}$ ) in the Saharanpur, Muzaffarnagar, Meerut, Baghpat, Ghaziabad, Noida and Greater Noida districts of western Uttar Pradesh and merged in the Yamuna River at Greater Noida. The Hindon River obtain the treated or untreated sewage and industrial effluents of about 45 major industries including sugar mills, distilleries, paper mills and Food processing industries during her journey. The Hindon River is adversely polluted due to the discharge of untreated or partially treated sewage wastewater and industrial effluent from ITC, Star Paper Mill Saharanpur and many other small scales chemical based industries. The Hindon River receives about 50 million liter wastewater (sewage and industrial effluents) per day through her tributaries like Dhamola, Paondhoi and Nagdehi River along with Star Paper Mill effluent drain at Paragpur Must village of Saharanpur city. The study area is characterized with loamy sandy soil and a wide variation in the mean monthly temperature from $12{ }^{\circ} \mathrm{C}$ in December and January and $44{ }^{\circ} \mathrm{C}$ in May and June. Average annual precipitation in the study area is about 10 to $20 \mathrm{~mm}$ from July to September thus this region comes under semiarid agro-climatic zone of the country. Therefore, evapotranspiration rate is also very high due to high temperature regime which affects the irrigation practices and their schedule in the study region. The farmers are using the water of Hindon River to irrigate their agricultural crops since more than 25 years. However, during the last decade rapid industrialization and urbanization severely deteriorated the quality of water flowing in the Hindon River. Now days the farmers are using the amalgam of domestic as well as industrial effluents in the cultivation of agricultural crops in the vicinity of the Hindon River at Saharanpur and other districts of the Uttar Pradesh state. The spinach (Spinacia oleracea), fenugreek (Trigonella foenum-graecum) and coriander (Coriandrum sativum) are the most common crops and widely cultivated in this region and used for making various dishes and green veggies as these green leafy vegetables are packed with minerals and vitamins (Kumar and Chopra, 2012b).

\section{Experimental design}

The present study was carried out at Paragpur Must village located at the bank of the Hindon River during the year 2015 (Figure 1). During the present study, the experimental area was divided into eighteen subplots $\left(4 \times 4 \mathrm{~m}^{2}\right)$ for the cultivation of spinach (Spinacia oleracea L.), fenugreek (Trigonella foenumgraecum L.) and coriander (Coriandrum sativum L.). Thus, six plots were used for the cultivation of each crop. The experiments were conducted under completely randomized design. The soils of the plots were prepared for sowing of the seeds of S. oleracea, $T$. foenum-graecum and C. sativum. The seeds of S. oleracea, $T$. foenum-graecum and $C$. sativum were sown during the end of the October, 2015. The composite effluent is pumped from the Hindon River using pumping sets to the agricultural fields through the plastic or PVC pipes and used to irrigate the 
agricultural crops through the small irrigation channels. The plants were irrigated once in a week with the composite (amalgam of sewage and industrial effluent) effluent of the Hindon River through the irrigation channel at the agriculture fields. Similarly, groundwater irrigated plants of S. oleracea; $T$. foenum-graecum and $C$. sativum were considered as controls.

\section{Collection of effluent, soil samples and their analysis}

The effluent used for irrigation of S. oleracea, T. foenum-graecum and C. sativum was analyzed for various physico-chemical and microbiological parameters viz., total dissolved solids (TDS), electrical conductivity (EC), $\mathrm{pH}$, biochemical oxygen demand $\left(\mathrm{BOD}_{5}\right)$, chemical oxygen demand (COD), chlorides $\left(\mathrm{Cl}^{-}\right)$, total Kjeldhal nitrogen (TKN), phosphate $\left(\mathrm{PO}_{4}{ }^{3-}\right)$, sulphate $\left(\mathrm{SO}_{4}{ }^{2-}\right)$, sodium $\left(\mathrm{Na}^{+}\right)$, potassium $\left(\mathrm{K}^{+}\right)$, calcium $\left(\mathrm{Ca}^{2+}\right)$, magnesium $\left(\mathrm{Mg}^{2+}\right)$, cadmium (Cd), chromium ( $\mathrm{Cr}$ ), copper ( $\mathrm{Cu}$ ), iron (Fe), manganese $(\mathrm{Mn})$, lead $(\mathrm{Pb})$, zinc $(\mathrm{Zn})$, total bacteria, total fungi, actinomycetes, total coliform and yeast following standard methods (Chaturvedi and Sankar, 2006; APHA, 2012). The samples of the soil (18) used for the cultivation of spinach (Spinacia oleracea L.), fenugreek (Trigonella foenum-graecum L.) and coriander (Coriandrum sativum L.) after composite effluent irrigation were collected from the agricultural fields of Paragpur Must village located at the bank of the Hindon River. Similarly, the ground water irrigated soil used for the cultivation of $S$. oleracea, $T$. foenum-graecum and $C$. sativum was considered as control. The soil samples were analyzed for various physico-chemical and microbiological parameters viz., EC, $\mathrm{pH}, \mathrm{Cl}^{-}, \mathrm{TOC}, \mathrm{TKN}, \mathrm{PO}_{4}{ }^{3-}, \mathrm{SO}_{4}{ }^{2-}, \mathrm{Na}^{+}$, $\mathrm{K}^{+}, \mathrm{Ca}^{2+}, \mathrm{Mg}^{2+}, \mathrm{Cd}, \mathrm{Cr}, \mathrm{Cu}, \mathrm{Fe}, \mathrm{Mn}, \mathrm{Pb}, \mathrm{Zn}$, total bacteria, total fungi, actinomycetes, coliform bacteria and yeast following standard methods cited by Chaturvedi and Sankar (2006).
Collection of vegetable samples and their analysis

The samples of S. oleracea, T. foenum-graecum and C. sativum cultivated in the composite effluent and ground water (control) irrigated agricultural fields were procured from the local farmers of the Paragpur Must village. The samples were washed thoroughly and their root, stem, leaves and fruits were separated using a sharp knife. The samples were then oven dried and used for metals extraction using di acid $\left(\mathrm{H}_{2} \mathrm{SO}_{4}\right.$ and $\left.\mathrm{HClO}_{4}\right)$ digestion method separately. The samples of root, stem, leaves and fruits of $\mathrm{S}$. oleracea, $T$. foenum-graecum and $\mathrm{C}$. sativum were analyzed for $\mathrm{Cd}, \mathrm{Cr}, \mathrm{Cu}, \mathrm{Fe}, \mathrm{Mn}, \mathrm{Pb}, \mathrm{Zn}$ using atomic absorption spectrophotometer following standard methods (Chaturvedi and Sankar, 2006; APHA, 2012). The enrichment factor is the ratio of the mean metal concentration of the effluent irrigated sample and control (groundwater). The enrichment factor of different heavy metals in the soil and S. oleracea, T. foenumgraecum and C. sativum were calculated following the equation:

$$
\text { Enrichment Factor }\left(E_{f}\right)=\frac{\text { Mean metal concentration of sample }}{\text { Mean metal concentration of control }}
$$

\section{Statistical analysis of the data}

The data was statistically analyzed for one way analysis of variance (ANOVA) to determine the significant difference in the characteristics of soil and vegetable crops $S$. oleracea, $T$. foenum-graecum and $C$. sativum before and after composite effluent irrigation using SPSS 16 . Student $t$ test was performed to differentiate the characteristics of composite effluent and ground water using MS Excel 2013. Graphs were plotted using Origin 8.5 .

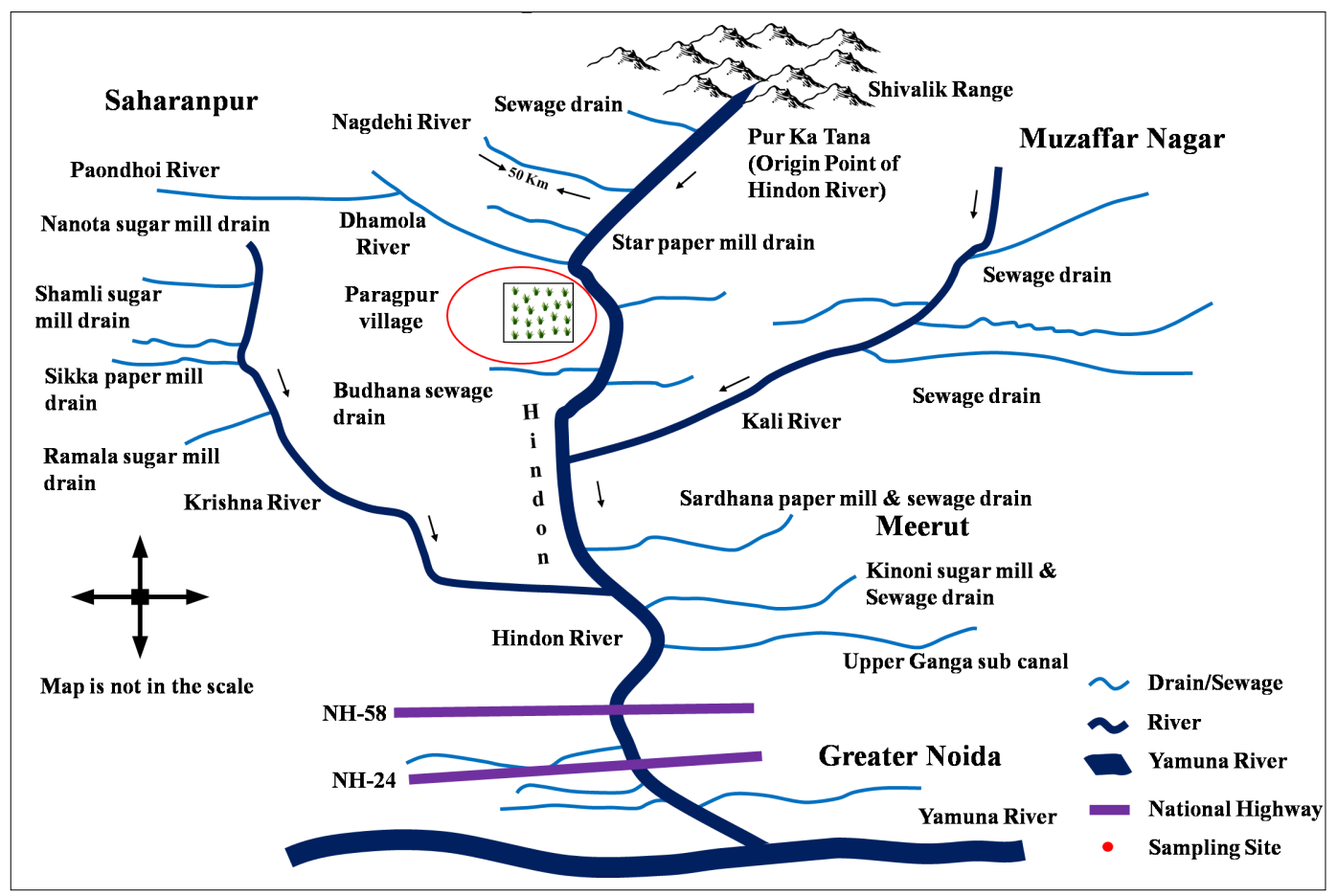

Figure 1. Map of the Hindon River showing different drains and sampling site at Saharanpur (Uttar Pradesh), India (Source: Lewis, 2007; Modified by the authors). 


\section{RESULTS AND DISCUSSION}

\section{Characteristics of composite effluents}

In the present study the characteristics of the composite effluent of Hindon River showed that the effluent was significantly $(P<0.05 / P<0.01)$ loaded with different physical (TDS, EC), chemical ( $\mathrm{pH}, \mathrm{BOD}_{5}, \mathrm{COD}, \mathrm{Cl}^{-}, \mathrm{TKN}, \mathrm{PO}_{4}{ }^{3-}, \mathrm{SO}_{4}{ }^{2-}, \mathrm{Na}^{+}, \mathrm{K}^{+}, \mathrm{Ca}^{2+}$, $\left.\mathrm{Mg}^{2+}\right)$, heavy metals $(\mathrm{Cd}, \mathrm{Cr}, \mathrm{Cu}, \mathrm{Fe}, \mathrm{Mn}, \mathrm{Pb}, \mathrm{Zn})$ and microbial (total bacteria, total fungi, total coliform and yeast) parameters in comparison to the ground water (Control) (Table 1). The values of TDS, $\mathrm{BOD}_{5}, \mathrm{COD}, \mathrm{Cl}^{-}, \mathrm{TKN}, \mathrm{Ca}^{2+}, \mathrm{Cd}, \mathrm{Cr}, \mathrm{Cu}, \mathrm{Fe}, \mathrm{Mn}$, $\mathrm{Pb}, \mathrm{Zn}$, total bacteria and coliform bacteria were observed beyond the irrigation standard prescribed by BIS (2010). The higher values of $\mathrm{EC}$ in the composite effluent indicated the presence of more ionic species $\left(\mathrm{Na}^{+}, \mathrm{K}^{+}, \mathrm{Ca}^{2+}, \mathrm{Mg}^{2+}, \mathrm{Cl}^{-}, \mathrm{PO}_{4}{ }^{3-}, \mathrm{SO}_{4}{ }^{2-}\right.$ ) and which may produce salinity of the soil if the effluent used frequently for irrigation. Kumar and Chopra (2012a) also reported more values of EC in the paper mill effluent due to the presence of higher ionic species in the paper mill effluent. More values of TDS, $\mathrm{BOD}_{5}, \mathrm{COD}$ and TKN of the composite effluent are associated with the presence of more oxidizable organic matter in the effluent and it is likely due to the discharge of sewage wastewater in the Hindon River (Table 1). The findings of the present study are in the close conformity of Muchuweti et al. (2006) who reported higher values of TDS, BOD 5, COD and TKN in the sewage and industrial effluent. The more contents of heavy metals $\mathrm{Cd}, \mathrm{Cr}, \mathrm{Cu}, \mathrm{Fe}, \mathrm{Mn}, \mathrm{Pb}$ and $\mathrm{Zn}$ were recorded in the composite effluent of Hindon River and it might be due to the discharge of industrial effluent from Star Paper mill, ITC and other small scale chemical based industries located in the vicinity of the Hindon River (Table 1). These findings are in the agreement of Arora et al. (2014) who reported higher values of $\mathrm{Cd}, \mathrm{Cr}$, $\mathrm{Cu}, \mathrm{Fe}, \mathrm{Mn}, \mathrm{Pb}$ and $\mathrm{Zn}$ in the industrial effluent discharged from the State Infrastructure and Industrial Development Corporation of Uttarakhand Limited (SIDCUL) Industrial Estate (IE), Haridwar in the Ranipur Rao River at Haridwar, India. The considerable microbial load as total bacteria, total fungi, coliform bacteria and yeast were observed in the composite effluent of the Hindon River and these characteristics are in the conformity of more organic matter in the effluent due to discharge of domestic sewage in the Hindon River. Pathak et al. (2011) also reported the more values of total bacteria, total fungi and coliform bacteria in the sewage effluent. Generally, our aquatic resources like lakes, steams and rivers are converting in to adversely polluted water courses due to discharge of the municipal sewage and industrial effluents due to inadequate, unsatisfactory, unscientific and costly treatment technologies as reported by Pathak et al. (2011). Therefore, the composite effluent flowing in the Hindon River contain higher chemical and microbial load due to discharge of the sewage wastewater and industrial effluent.

\section{Effects of composite effluent on soil characteristics}

The results of the present investigation showed that composite effluent irrigation significantly $(P \leq 0.05)$ altered the soil charac- teristics like $\mathrm{EC}, \mathrm{pH}, \mathrm{PO}_{4}{ }^{3-}, \mathrm{K}^{+}, \mathrm{Cd}, \mathrm{Cr}, \mathrm{Cu}, \mathrm{Fe}, \mathrm{Mn}$ and $\mathrm{Pb}$ in the soil used for the cultivation of $S$. oleracea, T. foenum-graecum and C. sativum were found to be highly significantly $(P \leq 0.01)$ different in comparison to the control soil. The values of $\mathrm{Cl}$; TOC, $\mathrm{TKN}, \mathrm{SO}_{4}{ }^{2-}, \mathrm{Na}^{+}, \mathrm{Ca}^{2+}, \mathrm{Mg}^{2+}$ and $\mathrm{Zn}$ in the soil used for the cultivation of $S$. oleracea, $T$. foenum-graecum and $C$. sativum were found to be highly significantly $(P \leq 0.01)$ different in comparison to the control soil. Moreover, the values of total bacteria, total fungi, actinomycetes, coliform bacteria and yeast in the soil used for the cultivation of $S$. oleracea, T. foenum-graecum and $C$. sativum were recorded more significantly $(P \leq 0.001)$ in comparison to the control soil (ground water irrigated soil) (Table 2). Additionally, the characteristics viz., $\mathrm{EC}, \mathrm{Cl}^{-}, \mathrm{TOC}, \mathrm{TKN}, \mathrm{PO}_{4}{ }^{3-}$, $\mathrm{SO}_{4}{ }^{2-}, \mathrm{Na}^{+}, \mathrm{K}^{+}, \mathrm{Ca}^{2+}, \mathrm{Mg}^{2+}, \mathrm{Cd}, \mathrm{Cr}, \mathrm{Cu}, \mathrm{Fe}, \mathrm{Mn}, \mathrm{Pb}, \mathrm{Zn}$, total bacteria, total fungi, actinomycetes, coliform bacteria and yeast of the soil used for the cultivation of S. oleracea, T. foenum-graecum and C. sativum were recorded to be positively correlated with the characteristics of the composite effluent (Table 3). The higher contents of TOC, TKN and $\mathrm{PO}_{4}{ }^{3-}$ in the composite effluent irrigated soil are associated with the more quantity of organic matter in the composite effluent as earlier reported by Arora et al. (2014). The more EC of the soil is directly related to the presence of more ionic $\left(\mathrm{Cl}{ }^{-}, \mathrm{PO}_{4}{ }^{3-}, \mathrm{SO}_{4}{ }^{2-}, \mathrm{Na}^{+}, \mathrm{K}^{+}, \mathrm{Ca}^{2+}, \mathrm{Mg}^{2+}\right)$ species in the composite effluent and which may contribute the soil salinity as earlier reported by Kumar and Chopra (2012a). The more contents of TOC are generally associated with the presence of more heavy metals ( $\mathrm{Cd}, \mathrm{Cr}, \mathrm{Cu}, \mathrm{Fe}, \mathrm{Mn}, \mathrm{Pb}$ and $\mathrm{Zn}$ ) in the soil. The higher contents of organic matter in the soil supports the more population of microorganisms in the soil as earlier reported by Javed et al. (2016). In addition to that the enrichment factor of different heavy metals $\mathrm{Cd}, \mathrm{Cr}, \mathrm{Cu}, \mathrm{Fe}, \mathrm{Mn}$, $\mathrm{Pb}$ and $\mathrm{Zn}$ in the soil used for the cultivation of S. oleracea, $T$. foenum-graecum and $C$. sativum were recorded in the order of $\mathrm{Pb}$ $>\mathrm{Zn}>\mathrm{Mn}>\mathrm{Fe}>\mathrm{Cd}>\mathrm{Cr}>\mathrm{Cu}$ for S. oleracea, $\mathrm{Pb}>\mathrm{Mn}>\mathrm{Fe}>\mathrm{Zn}$ $>\mathrm{Cr}>\mathrm{Cd}>\mathrm{Cu}$ for T. foenum-graecum and $\mathrm{Mn}>\mathrm{Pb}>\mathrm{Cr}>\mathrm{Fe}>\mathrm{Zn}$ $>\mathrm{Cd}>\mathrm{Cu}$ for $\mathrm{C}$. sativum after composite effluent irrigation (Figure 2). Thus, the increase in the various attributes of the soil used for the cultivation of S. oleracea, T. foenum-graecum and $C$. sativum are in the conformity of the presence of the chemicals, heavy metals and microorganisms in the composite effluent flowing in the Hindon River and used for the irrigation practices by the adjoining farmers. Therefore, composite effluent irrigation significantly increased the chemicals, heavy metals and microorganisms in the soil used for the cultivation of S. oleracea, T. foenum-graecum and C. sativum in the vicinity of the Hindon River.

Translocation and enrichment of heavy metals in vegetable crops

During the present investigation composite effluent irrigation significantly $(P \leq 0.05 / P \leq 0.01)$ increased the contents of heavy metals $\mathrm{Cd}, \mathrm{Cr}, \mathrm{Cu}, \mathrm{Fe}, \mathrm{Mn}, \mathrm{Pb}$ and $\mathrm{Zn}$ in different parts (root, stem, leaves and fruits) of $S$. oleracea, T. foenum-graecum and $C$. sativum in comparison to control (Tables 4, 5). The translocation of different heavy metals $\mathrm{Cd}, \mathrm{Cr}, \mathrm{Cu}, \mathrm{Fe}, \mathrm{Mn}, \mathrm{Pb}$ and $\mathrm{Zn}$ in the $\mathrm{S}$. 
oleracea were observed in the order of leaves $>$ stem $>$ root $>$ fruit for $\mathrm{Cd}$, root $>$ stem $>$ leaves $>$ fruit for $\mathrm{Cr}$ and $\mathrm{Pb}$, leaves $>$ stem > fruit > root for $\mathrm{Cu}$ and $\mathrm{Mn}$, leaves $>$ fruit $>$ stem $>$ root for Fe and $\mathrm{Zn}$ after composite effluent irrigation (Figure 3 ). The order of these metals in T. foenum-graecum was noted as leaves $>$ stem > root > fruits for $\mathrm{Cd}$ and $\mathrm{Cu}$, root $>$ stem > leaves > fruit fro $\mathrm{Cr}$ and $\mathrm{Pb}$, leaves $>$ fruit $>$ stem $>$ root for $\mathrm{Fe}$, leaves $>$ stem $>$ fruit $>$ root for $\mathrm{Mn}$ and leaves $>$ fruit $>$ stem $>$ root for $\mathrm{Zn}$ after composite effluent irrigation (Figure 4). Similarly, the translocation of these heavy metals in $C$. sativum was recorded in the order of leaves $>$ stem $>$ root $>$ fruit fro $\mathrm{Cd}$, root $>$ stem $>$ leaves $>$ fruit for $\mathrm{Cr}$ and $\mathrm{Pb}$, leaves $>$ stem $>$ fruit $>$ root for $\mathrm{Cu}$, Fe and $\mathrm{Mn}$, leaves $>$ fruit $>$ stem $>$ root for $\mathrm{Zn}$ after composite effluent irrigation (Figure 5). Therefore, diverse translocation of different heavy metals $\mathrm{Cd}, \mathrm{Cr}, \mathrm{Cu}, \mathrm{Fe}, \mathrm{Mn}, \mathrm{Pb}$ and $\mathrm{Zn}$ was observed in different parts of $S$. oleracea, $T$. foenum-graecum and $C$. sativum and it might be due to the specific nature of these plants for the translocation of these metals. In the present study, the enrichment of $\mathrm{Cd}, \mathrm{Cr}, \mathrm{Cu}, \mathrm{Fe}, \mathrm{Mn}, \mathrm{Pb}$ and $\mathrm{Zn}$ was recorded in the order of $\mathrm{Cd}>\mathrm{Zn}>\mathrm{Pb}>\mathrm{Fe}>\mathrm{Cr}>\mathrm{Mn}>\mathrm{Cu}$ for S. oleracea, $\mathrm{Cd}>\mathrm{Zn}>\mathrm{Fe}>$ $\mathrm{Mn}>\mathrm{Pb}>\mathrm{Cr}>\mathrm{Cu}$ for T. foenum-graecum and $\mathrm{Cd}>\mathrm{Zn}>\mathrm{Pb}>\mathrm{Fe}>$ $\mathrm{Cu}>\mathrm{Mn}>\mathrm{Cr}$ for $\mathrm{C}$. sativum after irrigation with composite effluent (Figure 6). The enrichment ant translocation of $\mathrm{Cd}, \mathrm{Cr}, \mathrm{Cu}$, $\mathrm{Fe}, \mathrm{Mn}, \mathrm{Pb}$ and $\mathrm{Zn}$ in S. oleracea, T. foenum-graecum and $\mathrm{C}$. sativum was recorded to be plant part specific and it is likely due to the specific uptake strategy for different heavy metals and protection mechanism of the crop plants against the toxicity of the heavy metals as earlier reported by Muchuweti et al. (2006). Although, the contents of $\mathrm{Cr}, \mathrm{Cu}, \mathrm{Fe}, \mathrm{Mn}, \mathrm{Pb}$ and $\mathrm{Zn}$ except $\mathrm{Cd}$ in the $S$. oleracea, $T$. foenum-graecum and $C$. sativum were recorded below the permissible limit of $\mathrm{Cd}\left(0.20 \mathrm{mg} \mathrm{Kg}^{-1}\right), \mathrm{Cr}(2.30 \mathrm{mg}$ $\mathrm{Kg}^{-1}$ ), $\mathrm{Cu}\left(40.0 \mathrm{mg} \mathrm{Kg}^{-1}\right)$ and $\mathrm{Zn}\left(60.0 \mathrm{mg} \mathrm{Kg}^{-1}\right)$ prescribed by FAO/WHO (2011) but long term irrigation practices may enhance the gradual build up of these heavy metals in the vegetable crops and pose a serious health hazard. Kumar and Chopra (2013) also reported the diverse accumulation of $\mathrm{Cd}, \mathrm{Cr}, \mathrm{Cu}, \mathrm{Fe}$, $\mathrm{Mn}, \mathrm{Pb}$ and $\mathrm{Zn}$ in the root, stem, leaves and fruits of French bean (Phaseolus vulgaris L.) grown in sewage sludge amended soil.

Table 1. Characteristics of groundwater, composite effluent discharged in Hindon River and BIS standards of effluent disposal.

\begin{tabular}{|c|c|c|c|}
\hline Parameter & Groundwater (control) & Composite effluent & BIS disposal standards \\
\hline $\mathrm{TDS}\left(\mathrm{mg} \mathrm{L}^{-1}\right)$ & $198.50 \pm 3.65$ & $5676.00^{* * *} \pm 5.85$ & 1900 \\
\hline $\mathrm{EC}\left(\mathrm{dS} \mathrm{cm} \mathrm{cm}^{-1}\right)$ & $0.34 \pm 0.04$ & $8.96^{* * *} \pm 0.08$ & - \\
\hline $\mathrm{pH}$ & $7.50 \pm 0.12$ & $8.82^{*} \pm 0.14$ & $5.5-9.0$ \\
\hline $\mathrm{BOD}_{5}\left(\mathrm{mg} \mathrm{L}^{-1}\right)$ & $3.83 \pm 1.06$ & $1238.96^{* * *} \pm 6.90$ & 100 \\
\hline $\operatorname{COD}\left(\mathrm{mg} \mathrm{L}^{-1}\right)$ & $5.88 \pm 0.32$ & $1699.78^{* * *} \pm 5.80$ & 250 \\
\hline $\mathrm{Cl}^{-}\left(\mathrm{mg} \mathrm{L}^{-1}\right)$ & $148.52 \pm 2.15$ & $658.47^{* *} \pm 3.67$ & 500 \\
\hline $\mathrm{TKN}\left(\mathrm{mg} \mathrm{L}^{-1}\right)$ & $24.27 \pm 0.55$ & $118.24^{* *} \pm 2.99$ & 100 \\
\hline $\mathrm{PO}_{4}^{3-}\left(\mathrm{mg} \mathrm{L}^{-1}\right)$ & $0.14 \pm 0.02$ & $219.78^{* * *} \pm 2.81$ & - \\
\hline $\mathrm{SO}_{4}{ }^{2-}\left(\mathrm{mg} \mathrm{L}^{-1}\right)$ & $17.64 \pm 0.36$ & $684.36^{* * *} \pm 4.19$ & 1000 \\
\hline $\mathrm{Na}^{+}\left(\mathrm{mg} \mathrm{L}^{-1}\right)$ & $9.65 \pm 0.74$ & $219.58^{* * *} \pm 3.22$ & - \\
\hline $\mathrm{K}^{+}\left(\mathrm{mg} \mathrm{L}^{-1}\right)$ & $5.54 \pm 0.88$ & $278.37^{* * *} \pm 3.41$ & - \\
\hline $\mathrm{Ca}^{2+}\left(\mathrm{mg} \mathrm{L}^{-1}\right)$ & $23.46 \pm 1.20$ & $662.39^{* * *} \pm 6.57$ & 200 \\
\hline $\mathrm{Mg}^{2+}\left(\mathrm{mg} \mathrm{L}^{-1}\right)$ & $12.15 \pm 0.87$ & $158.96^{* * *} \pm 3.67$ & - \\
\hline $\mathrm{Cd}\left(\mathrm{mg} \mathrm{L}^{-1}\right)$ & $0.01 \pm 0.00$ & $5.24^{* * *} \pm 0.09$ & 2.00 \\
\hline $\mathrm{Cr}\left(\mathrm{mg} \mathrm{L}^{-1}\right)$ & $0.01 \pm 0.00$ & $2.26^{* * *} \pm 0.08$ & 2.00 \\
\hline $\mathrm{Cu}\left(\mathrm{mg} \mathrm{L}^{-1}\right)$ & $0.04 \pm 0.00$ & $6.78^{* * *} \pm 0.16$ & 3.00 \\
\hline $\mathrm{Fe}\left(\mathrm{mg} \mathrm{L}^{-1}\right)$ & $0.28 \pm 0.02$ & $14.86^{* * *} \pm 0.24$ & 1.00 \\
\hline $\mathrm{Mn}\left(\mathrm{mg} \mathrm{L}^{-1}\right)$ & $0.02 \pm 0.00$ & $4.45^{* * *} \pm 0.12$ & 1.00 \\
\hline $\mathrm{Pb}\left(\mathrm{mg} \mathrm{L}^{-1}\right)$ & $0.01 \pm 0.00$ & $0.28^{* * *} \pm 0.02$ & 1.00 \\
\hline $\mathrm{Zn}\left(\mathrm{mg} \mathrm{L}^{-1}\right)$ & $0.06 \pm 0.00$ & $9.84^{* * *} \pm 0.55$ & 15.00 \\
\hline Total bacteria $\left(\mathrm{CFU} \mathrm{ml}{ }^{-1}\right.$ ) & $4.8 \times 10^{3} \pm 4.56$ & $7.96 \times 10^{16^{* * *}} \pm 3.75$ & 10000 \\
\hline Total Fungi (CFU ml ${ }^{-1}$ ) & $5.7 \times 10^{2} \pm 6.32$ & $5.7 \times 10^{8^{* * *}} \pm 2.85$ & - \\
\hline Actinomycetes (CFU ml ${ }^{-1}$ ) & $\mathrm{BCL}$ & $\mathrm{BCL}$ & - \\
\hline Total coliform (MPN $100 \mathrm{ml}^{-1}$ ) & $2.4 \times 10^{2} \pm 1.85$ & $6.87 \times 10^{19^{* * *}} \pm 3.15$ & 5000 \\
\hline Yeasts (CFU ml ${ }^{-1}$ ) & $1.20 \times 10^{3} \pm 4.69$ & $8.90 \times 10^{14^{* * *}} \pm 4.26$ & - \\
\hline
\end{tabular}

Least Squares Means; ns, ${ }^{*},{ }^{* *},{ }^{* * *}$ non-significant or significantly different to the control at $P \leq 0.05$ or $P \leq 0.01$, or $P \leq 0.001$, respectively; BCL- Below countable limit 
Table 2. Effects of composite effluent irrigation on soil characteristics used for the cultivation of S. oleracea, T. foenum-graecum and C. sativum.

\begin{tabular}{|c|c|c|c|c|}
\hline \multirow{2}{*}{ Parameter } & \multirow{2}{*}{$\begin{array}{l}\text { Groundwater } \\
\text { irrigated soil } \\
\text { (control) }\end{array}$} & \multicolumn{3}{|c|}{ Composite effluent irrigated soil } \\
\hline & & S. oleracea & T. foenum-graecum & C. sativum \\
\hline $\mathrm{EC}\left(\mathrm{dS} \mathrm{cm}^{-1}\right)$ & $1.92 \pm 0.05$ & $5.66^{*} \pm 1.02$ & $7.78^{*} \pm 1.04$ & $9.86^{*} \pm 1.08$ \\
\hline $\mathrm{pH}$ & $7.64 \pm 0.14$ & $7.94^{\mathrm{ns}} \pm 0.16$ & $8.15^{\mathrm{ns}} \pm 0.18$ & $8.52^{*} \pm 0.21$ \\
\hline $\mathrm{Cl}^{-1}\left(\mathrm{mg} \mathrm{Kg}^{-1}\right)$ & $45.87 \pm 1.26$ & $134.55^{* *} \pm 2.45$ & $222.50^{* *} \pm 3.27$ & $187.45^{\prime \prime} \pm 1.88$ \\
\hline $\mathrm{TOC}\left(\mathrm{mg} \mathrm{Kg}^{-1}\right)$ & $1.08 \pm 0.09$ & $6.85^{* *} \pm 1.02$ & $8.66^{* *} \pm 0.08$ & $10.43^{* * * \pm} \pm 0.11$ \\
\hline $\mathrm{TKN}\left(\mathrm{mg} \mathrm{Kg}^{-1}\right)$ & $36.88 \pm 1.10$ & $82.36^{* *} \pm 2.01$ & $174.33^{* *} \pm 2.18$ & $295.29^{\prime \prime} \pm 2.36$ \\
\hline $\mathrm{PO}_{4}^{3-}\left(\mathrm{mg} \mathrm{Kg}^{-1}\right)$ & $64.24 \pm 1.07$ & $96.79^{*} \pm 1.14$ & $143.85^{*} \pm 1.06$ & $184.25^{\prime \prime} \pm 1.18$ \\
\hline $\mathrm{SO}_{4}^{2-}\left(\mathrm{mg} \mathrm{Kg}^{-1}\right)$ & $124.50 \pm 1.35$ & $345.60^{* * *} \pm 1.26$ & $458.30^{* *} \pm 1.28$ & $388.60^{* *} \pm 1.34$ \\
\hline $\mathrm{Na}^{+}\left(\mathrm{mg} \mathrm{Kg}^{-1}\right)$ & $25.48 \pm 0.52$ & $133.96^{* *} \pm 0.64$ & $160.85^{* *} \pm 0.88$ & $177.86 \pm 0.88$ \\
\hline $\mathrm{K}^{+}\left(\mathrm{mg} \mathrm{Kg}^{-1}\right)$ & $165.88 \pm 0.94$ & $192.86^{\mathrm{ns}} \pm 0.78$ & $248.68^{*} \pm 0.67$ & $278.98^{*} \pm 0.85$ \\
\hline $\mathrm{Ca}^{2+}\left(\mathrm{mg} \mathrm{Kg}^{-1}\right)$ & $29.67 \pm 1.32$ & $269.88^{* *} \pm 1.42$ & $298.65^{* *} \pm 2.45$ & $228.52^{\prime \prime} \pm 2.36$ \\
\hline $\mathrm{Mg}^{2+}\left(\mathrm{mg} \mathrm{Kg}^{-1}\right)$ & $48.85 \pm 1.85$ & $172.32^{* *} \pm 1.65$ & $178.69^{* *} \pm 1.74$ & $185.55^{*} \pm 1.80$ \\
\hline $\mathrm{Cd}\left(\mathrm{mg} \mathrm{Kg}^{-1}\right)$ & $0.52 \pm 0.02$ & $1.56^{*} \pm 0.06$ & $1.94^{*} \pm 0.08$ & $2.11^{* *} \pm 0.04$ \\
\hline $\mathrm{Cr}\left(\mathrm{mg} \mathrm{Kg}^{-1}\right)$ & $0.19 \pm 0.06$ & $0.29^{n s} \pm 0.02$ & $0.74^{*} \pm 0.07$ & $0.99^{*} \pm 0.08$ \\
\hline $\mathrm{Cu}\left(\mathrm{mg} \mathrm{Kg}^{-1}\right)$ & $1.34 \pm 0.05$ & $1.78^{*} \pm 0.06$ & $2.06 \pm 0.05$ & $2.36^{* *} \pm 0.07$ \\
\hline $\mathrm{Fe}\left(\mathrm{mg} \mathrm{Kg}^{-1}\right)$ & $2.58 \pm 0.12$ & $8.86^{*} \pm 0.15$ & $12.96^{*} \pm 0.23$ & $10.78 \pm 0.34$ \\
\hline $\mathrm{Mn}\left(\mathrm{mg} \mathrm{Kg}^{-1}\right)$ & $0.56 \pm 0.32$ & $2.96^{*} \pm 0.21$ & $4.30^{*} \pm 0.08$ & $6.87^{* * *} \pm 0.75$ \\
\hline $\mathrm{Pb}\left(\mathrm{mg} \mathrm{Kg}^{-1}\right)$ & $0.08 \pm 0.00$ & $0.75^{*} \pm 0.02$ & $0.87^{* *} \pm 0.05$ & $0.69^{* *} \pm 0.04$ \\
\hline $\mathrm{Zn}\left(\mathrm{mg} \mathrm{Kg}^{-1}\right)$ & $1.78 \pm 0.01$ & $9.77^{* *} \pm 0.25$ & $8.36^{* *} \pm 0.23$ & $7.25^{* *} \pm 0.36$ \\
\hline Total bacteria $\left(\mathrm{CFU} \mathrm{g}^{-1}\right)$ & $5.63 \times 10^{2} \pm 4.25$ & $9.33 \times 10^{8^{* * *}} \pm 3.85$ & $5.86 \times 10^{6^{* * * *} \pm} \pm 6.25$ & $7.34 \times 10^{5^{* * *}} \pm 3.88$ \\
\hline Total Fungi (CFU ${ }^{-1}$ ) & $2.85 \times 10^{6} \pm 4.28$ & $5.60 \times 10^{12^{* * *}} \pm 3.87$ & $4.87 \times 10^{9 * * x} \pm 5.10$ & $4.8 \times 10^{7^{* * *}} \pm 6.00$ \\
\hline Actinomycetes $\left(\right.$ CFU g ${ }^{-1}$ ) & $5.30 \times 10^{4} \pm 5.00$ & $3.56 \times 10^{10^{* * * *}} \pm 8.57$ & $6.44 \times 10^{12^{* * *}} \pm 7.65$ & $8.70 \times 10^{9 * * *} \pm 6.48$ \\
\hline Total coliforms (MPN $100 \mathrm{~g}^{-1}$ ) & $4.87 \times 10^{3} \pm 6.35$ & $7.58 \times 10^{15^{* * *}} \pm 5.87$ & $4.82 \times 10^{14^{* x *}} \pm 7.58$ & $4.80 \times 10^{10^{* * * *}} \pm 8.50$ \\
\hline Yeasts $\left(\right.$ CFU g $\left.{ }^{-1}\right)$ & $5.46 \times 10^{5} \pm 7.45$ & $8.90 \times 10^{8^{* * * *}} \pm 4.50$ & $7.65 \times 10^{9 * * *} \pm 6.20$ & $6.94 \times 10^{7 * * *} \pm 3.50$ \\
\hline
\end{tabular}

Least Squares Means; ns, ${ }^{*}{ }^{* *},{ }^{* * *}$ non-significant or significantly different to the control at $P \leq 0.05$ or $P \leq 0.01, P \leq 0.001$, respectively

Table 3. Coefficient of correlation ( $r$ ) between composite effluent and characteristics of the soil used for the cultivation of $S$. oleracea, T. foenum-graecum and $C$. sativum.

\begin{tabular}{|c|c|c|c|}
\hline Composite effluent/Soil characteristics & S. oleracea & T. foenum-graecum & C. sativum \\
\hline Composite effluent vs soil EC & +0.78 & +0.82 & +0.86 \\
\hline Composite effluent vs soil $\mathrm{Cl}^{-}$ & +0.90 & +0.90 & +0.92 \\
\hline Composite effluent vs soil TOC & +0.84 & +0.88 & +0.92 \\
\hline Composite effluent vs soil TKN & +0.88 & +0.90 & +0.94 \\
\hline Composite effluent vs soil $\mathrm{PO}_{4}{ }^{3-}$ & +0.80 & +0.86 & +0.94 \\
\hline Composite effluent vs soil $\mathrm{SO}_{4}{ }^{2-}$ & +0.92 & +0.94 & +0.96 \\
\hline Composite effluent vs soil $\mathrm{Na}^{+}$ & +0.72 & +0.72 & +0.78 \\
\hline Composite effluent vs soil $\mathrm{K}^{+}$ & +0.74 & +0.78 & +0.82 \\
\hline Composite effluent vs soil $\mathrm{Ca}^{2+}$ & +0.72 & +0.76 & +0.80 \\
\hline Composite effluent vs soil $\mathrm{Mg}^{2+}$ & +0.80 & +0.80 & +0.84 \\
\hline Composite effluent vs soil Cd & +0.90 & +0.94 & +0.96 \\
\hline Composite effluent vs soil $\mathrm{Cr}$ & +0.86 & +0.92 & +0.94 \\
\hline Composite effluent vs soil $\mathrm{Cu}$ & +0.92 & +0.94 & +0.96 \\
\hline Composite effluent vs soil Fe & +0.98 & +0.98 & +0.99 \\
\hline Composite effluent vs soil Mn & +0.70 & +0.72 & +0.76 \\
\hline Composite effluent vs soil $\mathrm{Pb}$ & +0.84 & +0.86 & +0.88 \\
\hline Composite effluent vs soil Zn & +0.92 & +0.96 & +0.98 \\
\hline Composite effluent vs soil Total bacteria & +0.64 & +0.97 & +0.99 \\
\hline Composite effluent vs soil Total fungi & +0.72 & +0.70 & +0.68 \\
\hline Composite effluent vs soil Actinomycetes & +0.62 & +0.60 & +0.56 \\
\hline Composite effluent vs soil Coliform bacteria & +0.70 & +0.66 & +0.64 \\
\hline Composite effluent vs soil Yeast & +0.74 & +0.72 & +0.70 \\
\hline
\end{tabular}


Table 4. ANOVA for the effects of heavy metals accumulated in S. oleracea, T. foenum-graecum and C. sativum irrigated with composite effluent.

\begin{tabular}{|c|c|c|c|c|c|c|c|}
\hline Source & $\mathrm{Cd}$ & $\mathrm{Cr}$ & $\mathrm{Cu}$ & $\mathrm{Fe}$ & Mn & $\mathrm{Pb}$ & Zn \\
\hline Composite effluent (CE) & $*$ & $*$ & ** & $* *$ & $*$ & $*$ & ** \\
\hline Ground water (GW) & ns & ns & ns & ns & ns & ns & ns \\
\hline $\begin{array}{l}\text { Entire plant (EP) } \\
\text { Interaction }\end{array}$ & $*$ & $*$ & $* *$ & $* *$ & $*$ & $*$ & ** \\
\hline $\mathrm{CE} \times \mathrm{GW} \times \mathrm{EP}$ & $*$ & $*$ & $* *$ & $* *$ & $*$ & $*$ & $* *$ \\
\hline
\end{tabular}

ns, ${ }^{*},{ }^{* *}$ not significant or significant at $P \leq 0.05$ or $P \leq 0.01$, ANOVA

Table 5. ANOVA for the effects of heavy metals translocated in plant parts of S. oleracea, T. foenum-graecum and C. sativum irrigated with composite effluent.

\begin{tabular}{|c|c|c|c|c|c|c|c|}
\hline Source & $\mathrm{Cd}$ & $\mathrm{Cr}$ & $\mathrm{Cu}$ & $\mathrm{Fe}$ & Mn & $\mathrm{Pb}$ & $\mathrm{Zn}$ \\
\hline Composite effluent (CE) & $*$ & $*$ & $* *$ & $* *$ & * & * & ** \\
\hline Ground water (GW) & ns & ns & ns & ns & ns & ns & ns \\
\hline $\begin{array}{l}\text { Plant parts (PP) } \\
\text { Interaction }\end{array}$ & $*$ & $*$ & * & * & $*$ & * & $*$ \\
\hline$\overline{C E} \times G W \times P P$ & $*$ & $*$ & $*$ & $*$ & $*$ & $*$ & $*$ \\
\hline
\end{tabular}

ns, ${ }^{*},{ }^{* *}$ not significant or significant at $P \leq 0.05$ or $P \leq 0.01$, ANOVA.

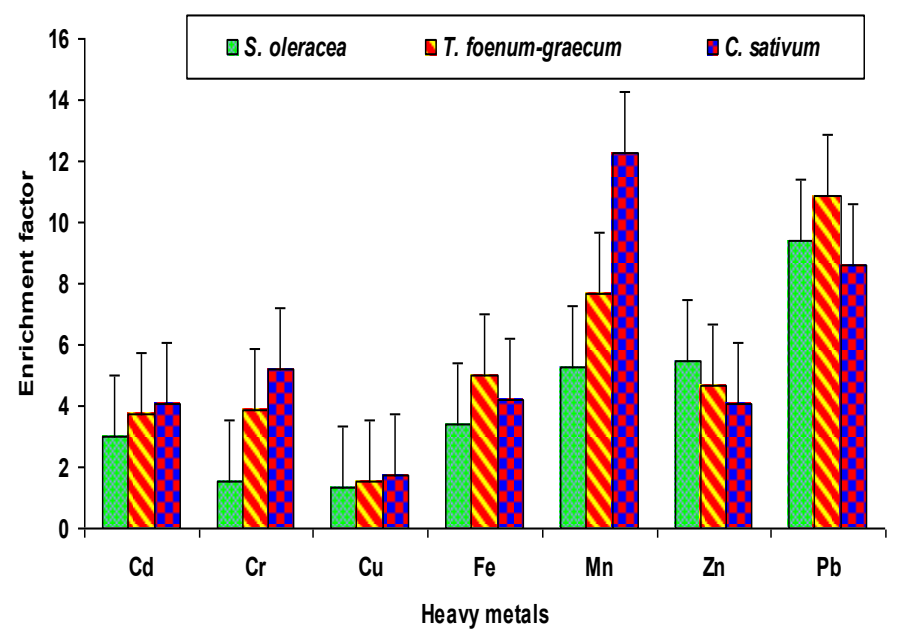

Figure 2. Enrichment factor of various heavy metals in the soil used for the cultivation of S. oleracea, T. foenum-graecum and C. sativum after irrigation with composite effluent. Error bars are standard error of the mean.

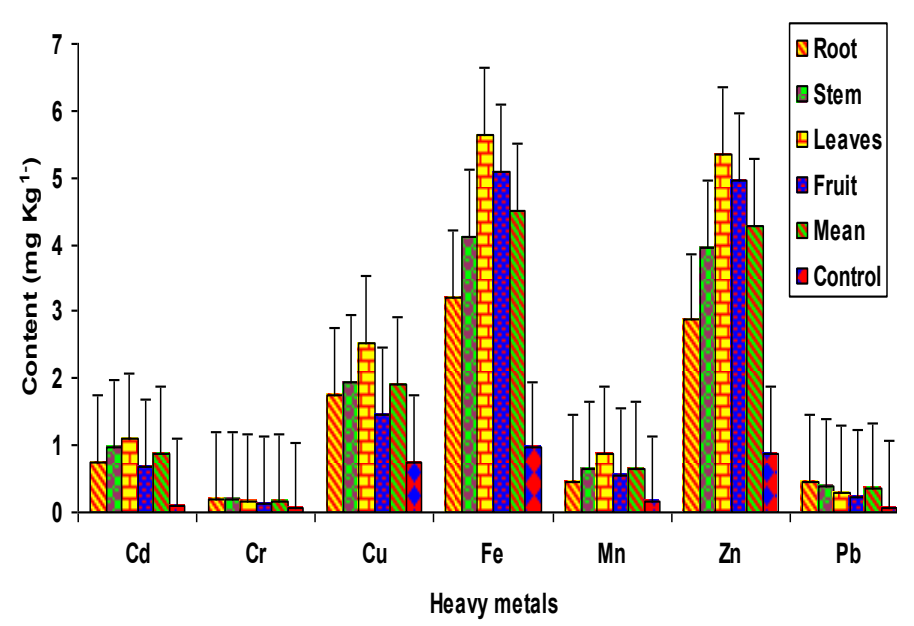

Figure 4. Translocation of various heavy metals in different parts of $T$. foenum-graecum after irrigation with composite effluent. Error bars are standard error of the mean.

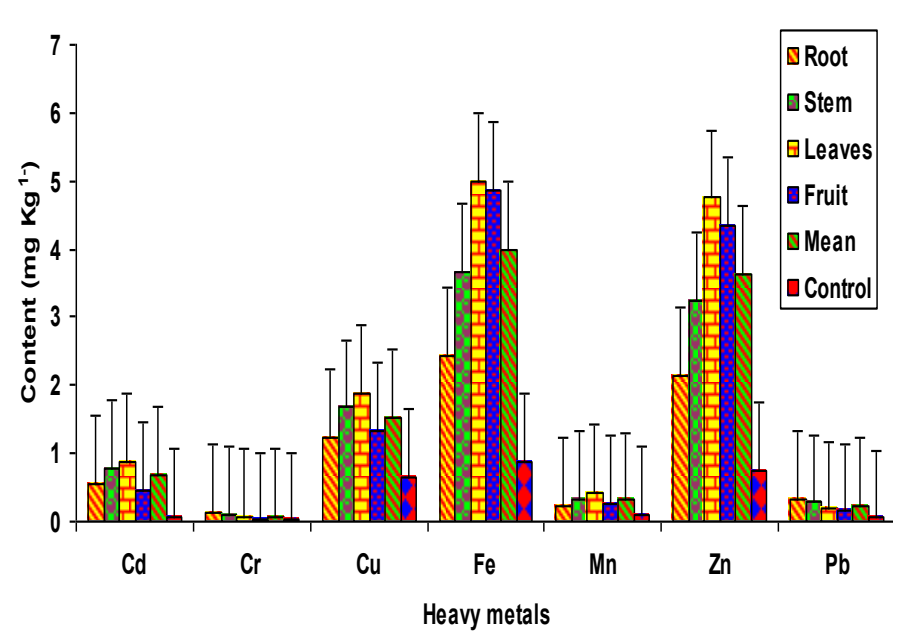

Figure 3. Translocation of various heavy metals in different parts of $S$. oleracea after irrigation with composite effluent. Error bars are standard error of the mean.

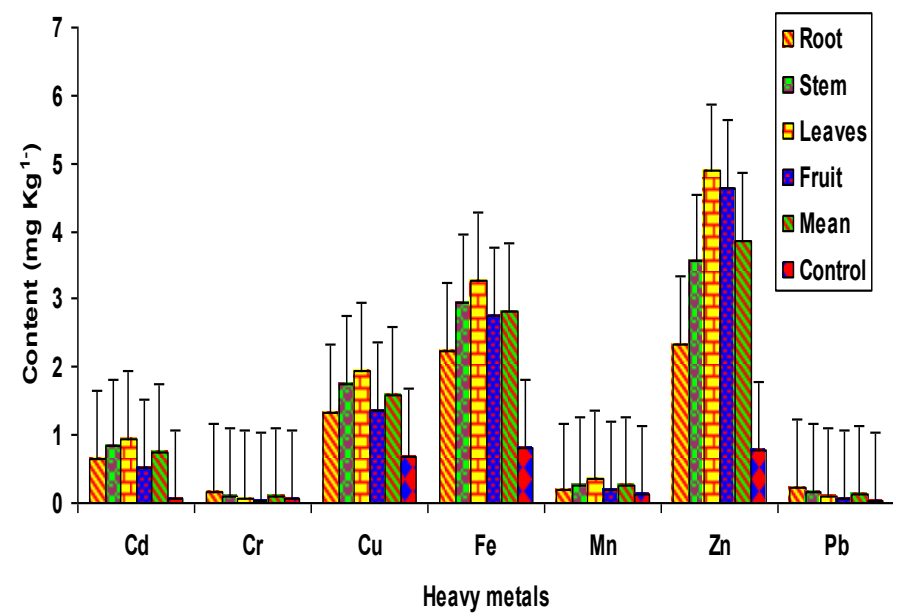

Figure 5. Translocation of various heavy metals in different parts of $C$. sativum after irrigation with composite effluent. Error bars are standard error of the mean. 


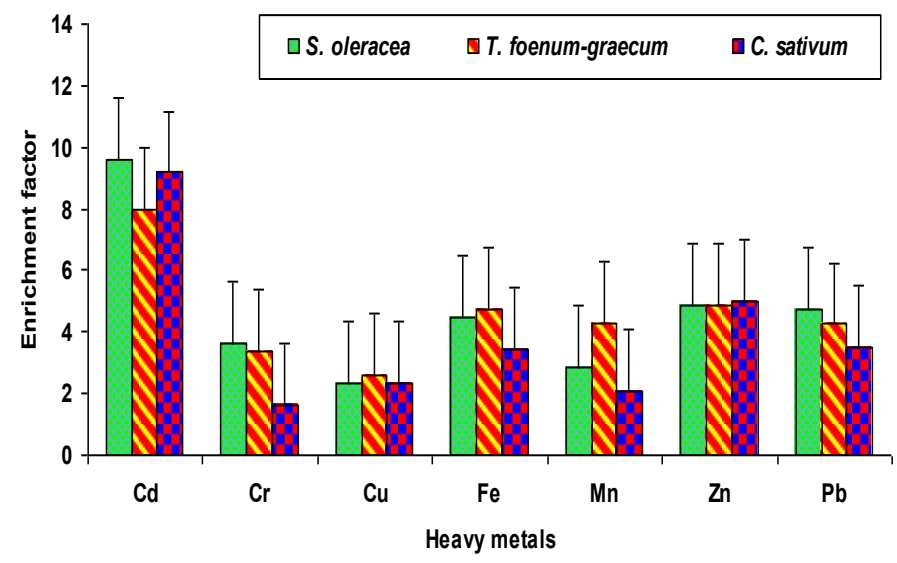

Figure 6. Enrichment factor of various heavy metals in S. oleracea, T. foenum -graecum and C. sativum after irrigation with composite effluent. Error bars are standard error of the mean.

\section{Conclusion}

In conclusion of this investigation, the Hindon River is being adversely polluted due to the disposal of the domestic sewage wastewater and industrial effluents of different industries located in the vicinity of the Hindon River. The composite effluent irrigation significantly $(P \leq 0.05 / P \leq 0.01 / P \leq 0.001)$ increased the EC, $\mathrm{Cl}^{-}, \mathrm{TOC}, \mathrm{TKN}, \mathrm{PO}_{4}{ }^{3-}, \mathrm{SO}_{4}{ }^{2-}, \mathrm{Na}^{+}, \mathrm{K}^{+}, \mathrm{Ca}^{2+}, \mathrm{Mg}^{2+}, \mathrm{Cd}, \mathrm{Cr}, \mathrm{Cu}$, $\mathrm{Fe}, \mathrm{Mn}, \mathrm{Pb}, \mathrm{Zn}$, total bacteria, total fungi, actinomycetes, coliform bacteria and yeast of the soil in comparison to control (ground water irrigated soil). Moreover, composite effluent irrigation significantly $(P \leq 0.01 / P \leq 0.001)$ increased the contents of $\mathrm{Cd}, \mathrm{Cr}, \mathrm{Cu}, \mathrm{Fe}, \mathrm{Mn}, \mathrm{Pb}$ and $\mathrm{Zn}$ in S. oleracea, T. foenum-graecum and $\mathrm{C}$. sativum. The translocation of $\mathrm{Cd}, \mathrm{Cr}, \mathrm{Cu}, \mathrm{Fe}, \mathrm{Mn}, \mathrm{Pb}$ and $\mathrm{Zn}$ in different parts like root, stem, leaves and fruits of $S$. oleracea, $T$. foenum-graecum and $C$. sativum were observed diverse in nature. The enrichment factor of $\mathrm{Cd}, \mathrm{Cr}, \mathrm{Cu}, \mathrm{Fe}, \mathrm{Mn}$, $\mathrm{Pb}$ and $\mathrm{Zn}$ were recorded in the order of $\mathrm{Cd}>\mathrm{Zn}>\mathrm{Pb}>\mathrm{Fe}>\mathrm{Cr}>$ $\mathrm{Mn}>\mathrm{Cu}$ for S. oleracea, $\mathrm{Cd}>\mathrm{Zn}>\mathrm{Fe}>\mathrm{Mn}>\mathrm{Pb}>\mathrm{Cr}>\mathrm{Cu}$ for $\mathrm{T}$. foenum-graecum and $\mathrm{Cd}>\mathrm{Zn}>\mathrm{Pb}>\mathrm{Fe}>\mathrm{Cu}>\mathrm{Mn}>\mathrm{Cr}$ for $\mathrm{C}$. sativum after irrigation with composite effluent. Thus, the quality of the water (truly wastewater) flowing in the Hindon River is not suitable for irrigation purposes and it may deteriorate the soil and vegetables quality and pose serious health hazards if used frequently for irrigation. Therefore, discharge of domestic sewage and industrial effluent should be stopped and irrigation practices should be banned. Further studies and regular monitoring should be required on the drainage activities and irrigation practices in the vicinity of the Hindon River.

Open Access: This is open access article distributed under the terms of the Creative Commons Attribution License, which permits unrestricted use, distribution, and reproduction in any medium, provided the original author(s) and the source are credited.

\section{REFERENCES}

APHA (2012). Standard methods for the examination of water and wastewater. American Public Health Association, 21st ed., Washington, DC pp. 2462.
Al-Lahham, O., El Assi, N.M. and Fayyad, M. (2003). Impact of treated wastewater irrigation on quality attributes and contamination of tomato fruit. Agriculture Water Management, 61: 51-62, https://doi.org/10.1016/S0378-3774(02) 00173-7

Arora, T., Mishra, A., Matta, G., Chopra, A.K., Kumar, A., Khanna, D.R. and Kumar, V. (2014). Human health risk assessment of temporal and spatial variations of ground water quality at a densely industrialized commercial complex at Haridwar, India. Journal of Applied and Natural Science, 6 (2): 825-843, https://doi.org/10.31018/jans.v6i2.543

Chaturvedi, R.K. and Sankar, K. (2006). Laboratory manual for the physicochemical analysis of soil, water and plant. Wildlife Institute of India, Dehradun, pp 97.

Chaturvedi, M. Kumar, V., Singh, D. and Kumar, S. (2013). Assessment of microbial load of some common vegetables among two different socioeconomic groups. International Food Research Journal, 20(5): 2927-2931, https:// www.cabdirect.org/cabdirect/abstract/20133386657

Chopra, A.K. Srivastava, S. and Kumar, V. (2011). Comparative study on agro-potentiality of Paper mill effluent and synthetic nutrient (DAP) on Vigna unguiculata L. (Walp) Cowpea. Journal of Chemical and Pharmaceutical Research, 3 (5): 151-165.

Chopra, A.K., Srivastava, S., Kumar, V. and Pathak, C. (2013). Agro-potentiality of distillery effluent on soil and agronomical characteristics of Abelmoschus esculentus L. (Okra). Environmental Monitoring and Assessment, 185: 6635-6644, https://doi.org/10.1007/s10661-012-3052-8

Clemente, R., Dickinson, N.M. and Lepp, N.W. (2008). Mobility of metals and metalloids in a multi-element contaminated soil 20 years after cessation of the pollution source activity. Environmental Pollution, 155: 254-261, https:// doi.org/10.1016/j.envpol.2007.11.024

FAO/WHO (2011). Joint FAO/WHO food standards programme codex committee on contaminants in foods, fifth session, pp. 64-89.

Javed Nawab, Khan, S., Ali, S., Hassan Sher, Rahman, Z., Khan, K., Tang, J. and Ahmad, A. (2016). Health risk assessment of heavy metals and bacterial contamination in drinking water sources: a case study of Malakand Agency, Pakistan. Environmental Monitoring and Assessment, 188: 286, https:// doi.org/10.1007/s10661-016-5296-1

Kumar, V. and Chopra, A.K. (2012a). Effect of paper mill effluent irrigation on agronomical characteristics of Vigna radiata (L.) in two different seasons. Communications in Soil Science and Plant Analysis, 43(16): 2142-2166, https:// doi.org/10.1080/00103624.2012.697236

Kumar, V. and Chopra, A.K. (2012b). Fertigation effect of distillery effluent on agronomical practices of Trigonella foenum-graecum L. (Fenugreek). Environmental Monitoring and Assessment, 184: 1207-1219, https://doi.org/10.1007/ s10661-011-2033-7

Kumar, V. and Chopra, A.K. (2013). Accumulation and translocation of metals in soil and different parts of French bean 
(Phaseolus vulgaris L.) amended with sewage sludge. Bulletin of Environmental Contamination and Toxicology, 92 (1): 103108, https://doi.org/10.1007/s00128-013-1142-0

Lewis, H. (2007). Hindon River: Gasping for breath. Janhit Foundation D-80 Shastri Nagar Meerut, Uttar Pradesh. pp. 55, http://www.janhitfoundation.in/pdf/Study\%20Reports/ Hindon-\%20Report-10-1-07.pdf

Muchuweti, M., Birkett, J.W., Chinyanga, E., Zvauya, R., Scrimshaw, M.D. and Lester, J.N. (2006). Heavy metal content of vegetables irrigated with mixture of wastewater and sewage sludge in Zimbabwe: Implications for human health. Agriculture, Ecosystem and Environment, 112: 41-48, https://doi.org/10.1016/j.agee.2005.04.028

Pathak, C., Chopra, A.K., Kumar, V. and Sharma, S. (2011). Effect of sewage-water irrigation on physico-chemical parameters with special reference to heavy metals in agricultural soil of Haridwar city. Journal of Applied and Natural Science, 3 (1): 108-113.

Qadir, M., Wichelns, D., Raschid-Sally, I., McCornik, P.G., Drechsel, P., Bahri, H. and Minhas, P.S. (2009). The challenges of wastewater irrigation in developing countries. Agriculture Water Management, 97(4): 561-568, https:// doi.org/10.1016/j.agwat.2008.11.004

Sharma, R.K., Agrawal, M. and Marshall, F. (2006). Heavy metals contamination in vegetables grown in wastewater irrigated areas of Varanasi, India. Bulletin of Environmental Contamination and Toxicology, 77: 312-318, https:// doi.org/10.1007/s00128-006-1065-0

Sharma, M.K., Jain, C.K. and Singh, O. (2014). Characterization of point sources and water quality assessment of River Hindon using water quality index. Journal of Indian Water Resource Society, 34 (1): 53-64.

Sridhara, C.N., Kamala, C.T., Samuel, S. and Raj, D. (2008). Assessing risk of heavy metals from consuming food grown on sewage irrigated soils and food chain transfer. Ecotoxicology and Environment Safety, 69: 513-524, https:// doi.org/10.1016/j.ecoenv.2007.04.013

Wang, J.F., Wang, G.X. and Wanyan, H. (2007). Treated wastewater irrigation effect on soil, crop and environment: Wastewater recycling in the Loess Area of China. Journal of Environmental Science, 19(9): 1093-1099, https:// www.ncbi.nlm.nih.gov/pubmed/17966515

Yadav, R.K., Goyal, B., Sharma, R.K., Dubey, S.K. and Minhas, P.S. (2002). Post irrigation impact of domestic sewage effluent on composition of soils, crops and ground water-A case study. Environment International, 28: 481-486, https:// doi.org/10.1016/S0160-4120(02)00070-3 